\title{
Values and Beliefs That Shape Cattle Breeding in Southwestern Burkina Faso
}

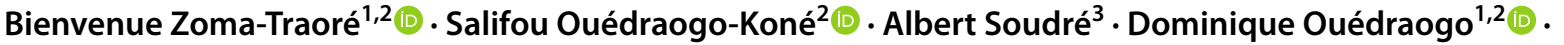 \\ Bernadette Yougbaré $^{1,4} \cdot$ Amadou Traoré $^{4} \cdot$ Negar Khayatzadeh $^{1}$. Gábor Mészáros ${ }^{1}$ (1) Pamela Anna Burger ${ }^{5}$ (1) . \\ Okeyo Ally Mwai ${ }^{6} \cdot$ Johann Sölkner ${ }^{1} \cdot$ Maria Wurzinger $^{1,7}\left([) \cdot\right.$ Lorenz Probst $^{7}$ (i)
}

Accepted: 31 May 2021 / Published online: 17 June 2021

(c) The Author(s) 2021

\begin{abstract}
Cattle production in southwestern Burkina Faso is under pressure because of resource scarcity, changing climate, and cattle diseases. Well-adapted local breeds, such as Lobi taurine cattle, are increasingly replaced by more productive exotic breeds. Community-based breeding programs (CBBPs) could be a viable option for preserving the breed and improving its productivity. Presuming that CBBPs would succeed only if they align with producers' beliefs and values, we relied on a combination of conceptual frameworks (theory of basic values, rural livelihood transitions) to explore the values and beliefs of cattle producers. Security was the respondents' dominant value in their aim to mitigate threats to livelihood, and it was closely linked to achievement in terms of harvest and animal quantity. Livestock-oriented respondents particularly valued conformity with accepted social roles, while achievement and power were more pronounced among crop-oriented respondents. We conclude that CBBPs, to be successful, will need to reduce threats to participants' livelihood and make benefits of participation immediately visible. We consider the emergence of trusted leadership from the community to be pivotal for creating momentum for novel arrangements in cattle keeping and feeding.
\end{abstract}

Keywords Values $\cdot$ Beliefs $\cdot$ Cattle breeding $\cdot$ Lobi taurine cattle $\cdot$ Southwestern Burkina Faso

Lorenz Probst

lorenz.probst@boku.ac.at

1 Division of Livestock Sciences, Department of Sustainable Agricultural Systems, University of Natural Resources and Life Sciences, Vienna, Austria

2 Institute of Rural Development, Nazi BONI University, Bobo-Dioulasso, Burkina Faso, Austria

3 Department of Life and Earth Sciences, Norbert ZONGO University of Koudougou, Koudougou, Burkina Faso, Austria

4 Department of Animal Production, Environmental and Agricultural Research Institute, Ouagadougou, Burkina Faso, Austria

5 Institute of Population Genetics, Department of Biomedical Sciences, University of Veterinary Medicine, Vienna, Austria

6 International Livestock Research Institute (ILRI), Nairobi, Kenya

7 Institute for Development Research, Department of Sustainable Agricultural Systems, University of Natural Resources and Life Sciences, Vienna, Austria

\section{Introduction}

\section{Community-based Breeding to Improve Livelihoods and Conserve Local Breeds}

Agriculture remains the primary source of livelihood for most smallholders in rural areas of the Global South (McIntyre et al. 2009), where livelihoods are challenged by the accelerating climate crisis, social dynamics, and degrading natural resources (Alvaredo et al. 2018; Cherlet et al. 2018; IPCC 2019). To address the resulting food security challenges, farmers have continuously adapted their practices (e.g., Reij et al. 2009). In southwestern Burkina Faso, the focus area of this study, cattle keeping is an essential part of agriculture-based livelihood strategies, and local breeds are part of traditions fulfilling social, cultural, and spiritual roles (e.g., FAO 2013). While local cattle breeds can contribute to the resilience of livestock-oriented livelihoods through their suitability to the specific environment, robustness and tolerance to diseases, livestock keepers have reduced their number in favor of "exotic" or crossbreed animals, which tend to have higher 
productivity and market value (Leroy et al. 2015). In our study area, indiscriminate crossbreeding of local Lobi taurine cattle with Fulani Zebu threatens the survival of the Lobi taurine breed (e.g., Mopaté et al. 2014) (Fig. 1).

Lobi taurine cattle are short $(90-106 \mathrm{~cm})$, light (150-200 kg) and adapt well to high temperatures, drought, and fodder variation. In the Lobi culture, the cattle have been important for bride price and spiritual offerings, and their meat as a specialty during festivities. Particularly relevant in terms of livelihood security is the breed's resistance to bovine trypanosomiasis, a disease that causes substantial livestock losses in West Africa (Belemsaga et al. 2005; Soudré et al. 2013; Mopaté 2015; Traoré et al. 2015; Dessie and Okeyo Mwai 2019; Yougbaré et al. 2020). In comparison, Fulani Zebu are taller $(120-150 \mathrm{~cm})$, heavier (250-400 kg) and more productive (meat and milk). However, the breed is susceptible to trypanosomiasis (Traoré et al. 2015; Grace et al. 2020). In the past, the two breeds were regarded as clearly associated with ethnic groups and their respective livelihood strategies, with Lobi (farmers) keeping mostly Lobi taurine, and Fulani (pastoralists) keeping mostly Zebu. However, in an earlier study conducted in the study area (Zoma-Traore et al. 2020), we found that the ethnic categorization no longer describes the realities of livelihood strategies in the area: numerous Lobi farmers have enlarged their herds and engaged in crossbreeding. Analogously, numerous Fulani livestock keepers engage in staple crop production and acknowledge the advantages of cattle crossbreeding due to the superior resistance of Lobi taurine cattle.

In this dynamic situation, Lobi taurine cattle have been classified as endangered since their declining numbers raise fears over the loss of their valuable genetic traits (e.g., Sokouri et al. 2009). Indeed, the Food and Agriculture Organization (FAO) $(2013,2015)$ has classified most local cattle breeds as endangered and recommends in vivo and in situ conservation through sustainable management and the establishment of breeding programs. In the context of low-input smallholder systems, community-based breeding programs (CBBPs) have emerged as a strategy to conserve and improve local breeds (e.g., Mueller et al. 2015). CBBPs are an attempt to bring together livestock keepers, scientists, and other stakeholders with the goal of jointly improving and sharing genetic resources. In contrast to conventional breeding programs, CBBPs focus on local genetic resources and farmer cooperation. Establishing locally relevant institutions can further facilitate joint marketing and collaboration beyond breeding. CBBPs should align closely with the needs of livestock keepers to ensure their commitment and participation (Mueller et al. 2015). While some earlier work on CBBPs has addressed questions of livestock keepers' knowledge, perceptions, and choices (e.g., Wurzinger and Gutierrez 2017; Martin-Collado et al. 2018), the focus in the literature has been mostly on technical aspects of breeding

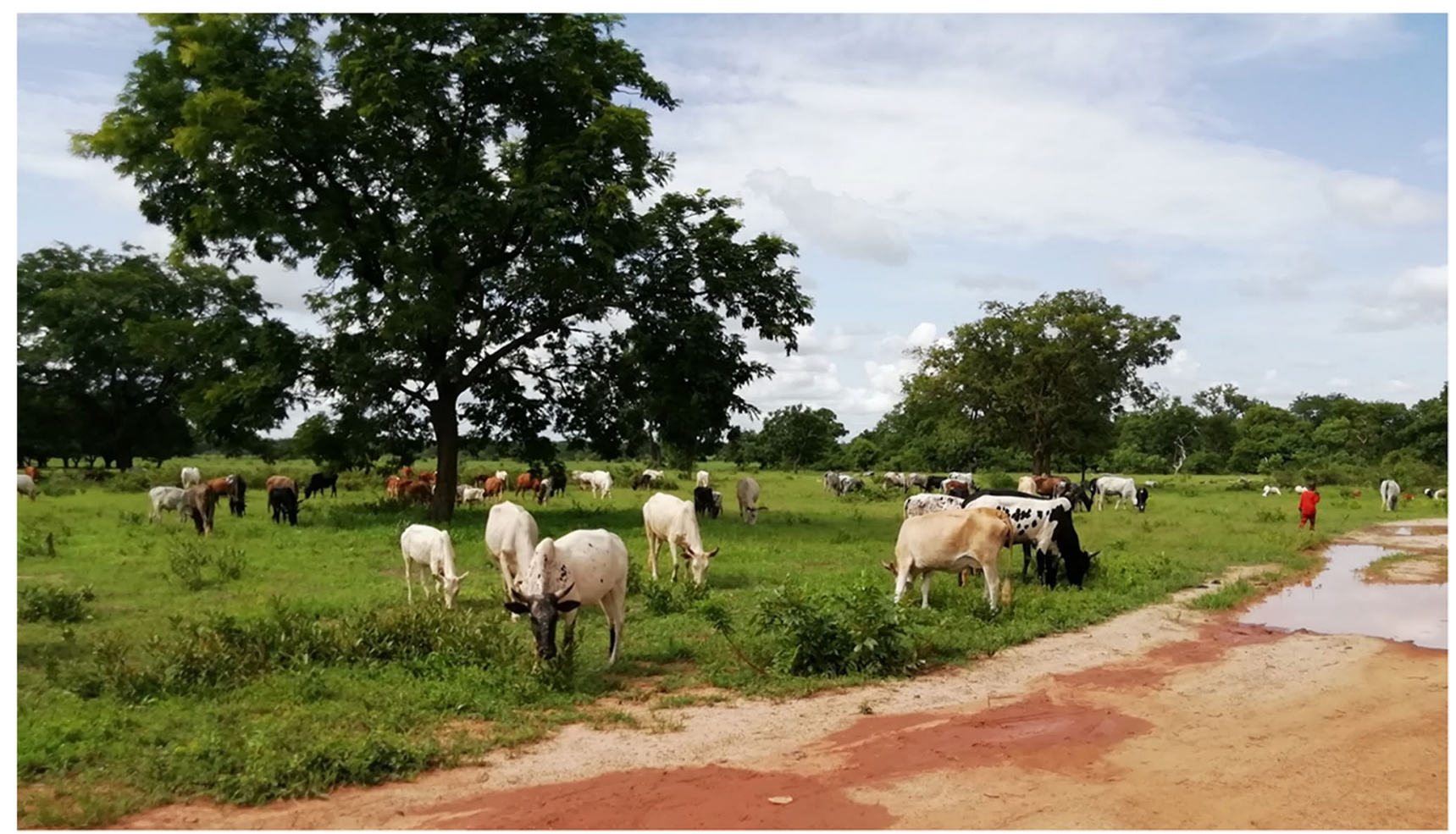

Fig. 1 A herd of Lobi taurine and Fulani Zebu crossbreed cattle grazing in Bouroum-Bouroum. Photo: B.Z.-T 
(e.g., selection criteria or exchange of breeding males). The purpose of the present study is, therefore, to understand the values and beliefs that shape choices by cattle keepers in southwestern Burkina Faso. From this understanding, we aim to derive practical insights relevant for facilitators of CBBPs.

\section{Agricultural Innovation in Smallholder Contexts}

For many decades, development interventions and research have aimed to increase productivity, income, and food security, as well as reduce poverty (e.g., Kassie et al. 2011). In smallholder contexts, changing agricultural practices (including livestock breeding) has been a common strategy to pursue these outcomes. The conventional perspective is that change occurs when technology and innovation diffuse from research and extension to farmers (see Röling 2009 for a summary). The main actors in this context are research and extension organizations, while farmers are expected to learn and adopt novel technologies (Jarrett 1985). Chambers et al. (1989) and others have criticized this conceptualization, instead emphasizing the agency of farmers, and proposing "farmers first" in experimenting with new technologies. These ideas have been taken up by more recent approaches that account for institutional, contextual, and individual dimensions of change, such as Agricultural Knowledge and Information Systems (AKIS) and Farming System Research (FSR) (e.g., Norman 2002). Current mainstream approaches conceptualize change in agricultural practices as an emerging property of Agricultural Innovation Systems (AIS) comprised of actors, their interactions, and institutions (Klerkx et al. 2012). Creating a condensed innovation system through a multi-stakeholder process is expected to produce more legitimate, sustainable, and contextualized outcomes. However, the success of these processes depends strongly on their institutional embedding (Schut et al. 2016).
In parallel to these process-oriented approaches, deterministic concepts of adoption remain common, including in the study area (e.g., Jahel et al. 2018). At a fundamental level, adoption studies assume rational individual choices constrained by external factors. However, this assumption has been questioned by many studies that argue that farmer decision-making is also grounded in values, norms and meanings that individuals 'construct' in relation to agricultural practices (e.g., Meijer et al. 2015; Bassi et al. 2019).

We acknowledge the recent 'ontological turn' in rural sociology, which asks whether the constructivist tradition's focus on human cognition and agency is sufficient to understand the constantly evolving, unpredictable tissue of interactions in agricultural practice (Darnhofer 2020). Nevertheless, our approach is rooted in the constructivist understanding of 'meaning-making' because we consider it essential in transdisciplinary research for development. We have therefore framed our analysis accordingly.

\section{Theoretical Framework: Values and Beliefs}

Inquiry into why farmers do what they do is a recurring theme in transdisciplinary research for development (e.g., Bassi et al. 2019). Various theories have been proposed to understand and predict behavior, including the Theory of Planned Behavior (TPB) (Ajzen 1991), Expected Utility Theory (EUT) (Mongin 1997), and Schwartz' (1992) theory of basic values. While TPB and EUT focus on intentions regarding a specific, proposed behavior, Schwartz' theory transcends specific actions or situations and investigates the relative importance of values and their trade-offs. Since our objective was to openly explore the values and beliefs of cattle keepers that shape their livelihood as well as cattle breeding choices, we considered Schwartz' theory the most appropriate for framing our investigation. The theory has been applied and discussed since the 1980s, and it has

Table 1 Analytical framework based on El Bilali et al. (2017) and Schwartz (1994)

\begin{tabular}{|c|c|c|}
\hline Domain & Subdomain & Description \\
\hline Landscape & & $\begin{array}{l}\text { larger-scale trends in the agro-ecosystem that cannot be directly influenced } \\
\text { at individual or community level }\end{array}$ \\
\hline Regime & & established societal practices and accepted rules \\
\hline Livelihood strategies & & assets and strategies used to achieve livelihood outcomes \\
\hline \multirow[t]{9}{*}{ Values } & Security & Personal and societal security, experienced as safety, harmony and stability \\
\hline & Power & Social status and prestige, control over people or resources \\
\hline & Achievement & Success through demonstrating competence according to social standards \\
\hline & Hedonism & Pleasure and gratification for oneself \\
\hline & Stimulation & Excitement, novelty and challenge in life \\
\hline & Self-direction & Independent thought and action \\
\hline & Universalism & Understanding and protection of welfare for all people and for nature \\
\hline & Benevolence & Caring for people with whom one is in frequent contact \\
\hline & Conformity & Following societal expectations and norms \\
\hline
\end{tabular}


been particularly influential in consumer studies. In the agricultural context, examples of successful application include farmer mental models of change in Sweden (Hansson and Suvi 2018), farmer water conservation practices in the US (Pradhananga and Davenport 2019), and value orientation in relation to climate change in Ethiopia (Etana et al. 2020).

Schwartz' theory of basic values positions values along two bipolar dimensions: openness to change/conservation and self-enhancement/self-transcendence. Within these dimensions, the theory specifies 10 values. Initially, Schwartz (1992) developed a research instrument that asked respondents to rate the importance assigned directly to a specific value. In the subsequent expansion of the basic values theory, Stern et al. (1999) proposed that values affect beliefs, which can turn into norms and actions (Value-belief-norm theory). While such clear sequential chains have been disputed in behavioral research, the existence of formal links is widely accepted. We therefore posit that respondents' belief statements, or propositions about 'what is' and 'why' are indicative of their values.

\section{Analytical Framework}

We developed an analytical framework to link the theoretical considerations to the specific research case at hand. To structure our investigation according to aspects of livestock keepers' livelihood, we referred to the concept of rural livelihood transitions (El Bilali et al. 2017) and distinguished among landscape, regime, and livelihood strategies. We also specified the 10 basic values based on Schwartz' (1994) 'conceptual facets' (Table 1). The analytical framework later served as the coding frame during deductive coding of the data.

\section{Materials and Methods}

\section{Study Sites and Sampling}

We conducted our research in the southwestern region of Burkina Faso, which is located in the mountainous SouthSudanian ecological zone (Fig. 2). Mean annual rainfall
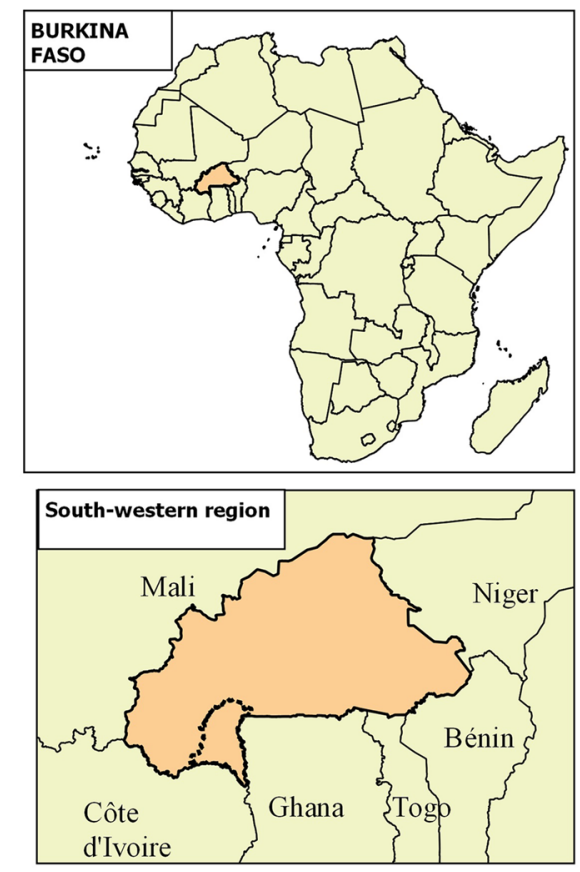

Legend

- study location

() town

South-western region

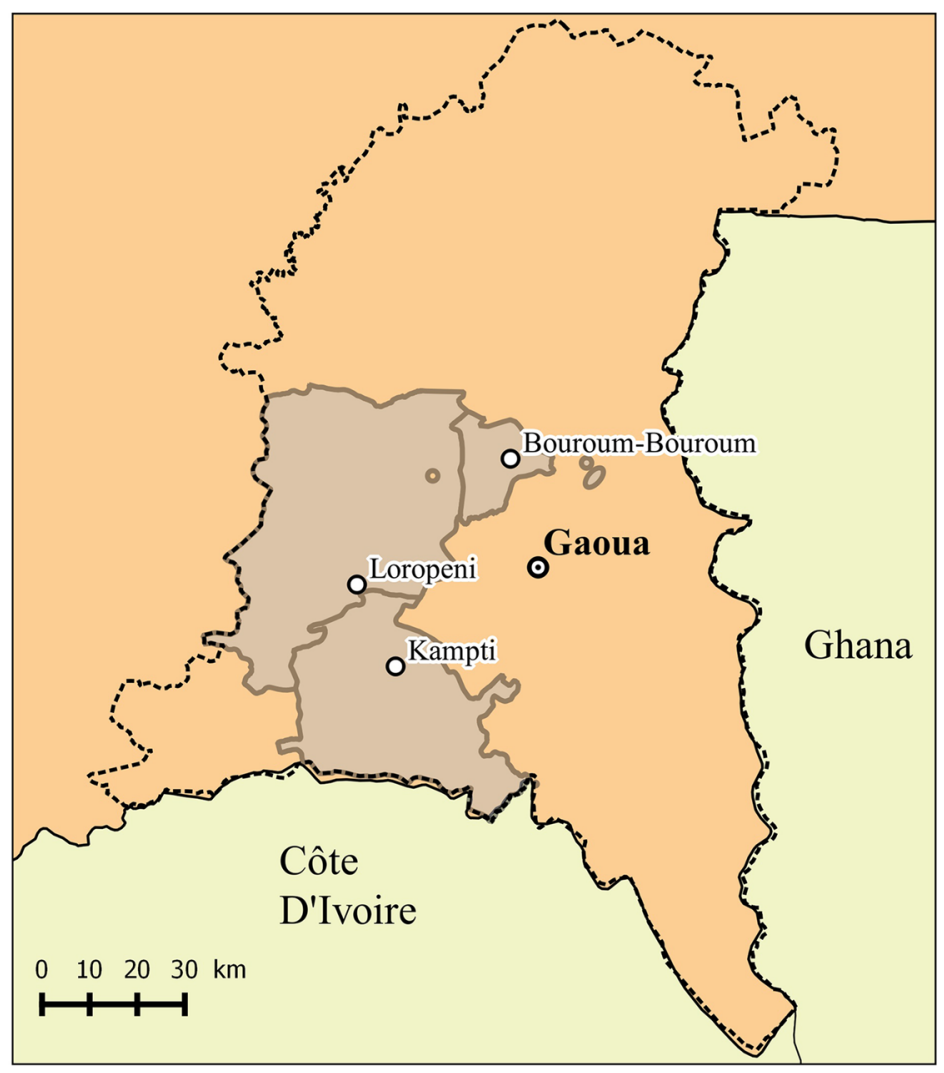

Data source: the National Topographic Database (BNDT)

Fig. 2 Location of the study sites 
ranges from 900 to $1200 \mathrm{~mm}$, and mean monthly temperatures range from 21 to $32{ }^{\circ} \mathrm{C}$. Different ethnic groups comprise the population of about 850,000 people: Lobi, Dagara, Birifo, Djan, and Pogouli are considered "local," while Mossi, Fulani, and Bobo are considered immigrants (INSD 2018). The population is growing at an annual rate of about $4.5 \%$, which includes net annual immigration of about $2 \%$ (INSD 2018). Cattle and crop production are the primary economic activities in the area (Ouédraogo et al. 2020).

We collected data in the administrative units of Bouroum-Bouroum, Kampti, and Loropeni in Poni province. Crop and cattle production in these units is growing through increases in farmed area and stocking density, which is typical for the region (INSD 2018). At the same time, rainfall patterns have become erratic, and parasite and disease pressure constrain livestock production (Zoma-Traoré et al. 2020).

Livelihood strategies and production systems in the region have traditionally been linked to ethnic groups. However, our exploratory analysis of production systems in the region (Zoma-Traoré et al. 2020) identified four distinct types ('clusters') as a more meaningful description of livelihood realities (Table 2).

While the clusters differed in terms of cattle management, division of labor, and the role of cattle in livelihood strategies more generally, the approach to cattle breeding (uncontrolled mating) was found to be the same across all four clusters. Another study in the area (Ouédraogo et al. 2020) established that livestock producers kept their own bulls, which they replaced from within the herd. That study also observed that the adult size of both cows and bulls was the most common criterion when livestock keepers deliberately selected breeding animals. Zoma-Traoré et al. (2021) confirmed that perceived animal performance was more important to livestock keepers than appearance. In all four production systems, breeding was not considered a key task in livestock management (Zoma-Traoré et al. 2020). Men typically dominated livestock-related interactions beyond the farm (e.g., purchase and sale, veterinary services), whereas women were often responsible for the care of the animals (e.g., watering, milking).

For this study to adequately capture the diversity of cattle production systems while maintaining a manageable number of respondents to allow for in-depth conversation and analysis, we applied simple random sampling to identify eight households from each of the four clusters established in Zoma-Traoré et al. (2020). In this way, we built on the purposive heterogeneous sampling frame and results of our earlier study. For testing the research instrument of the present study, two additional households were randomly selected from clusters II and III. Since we did not change the instrument after testing, we retained the data for analysis, giving a total sample of 34 households.

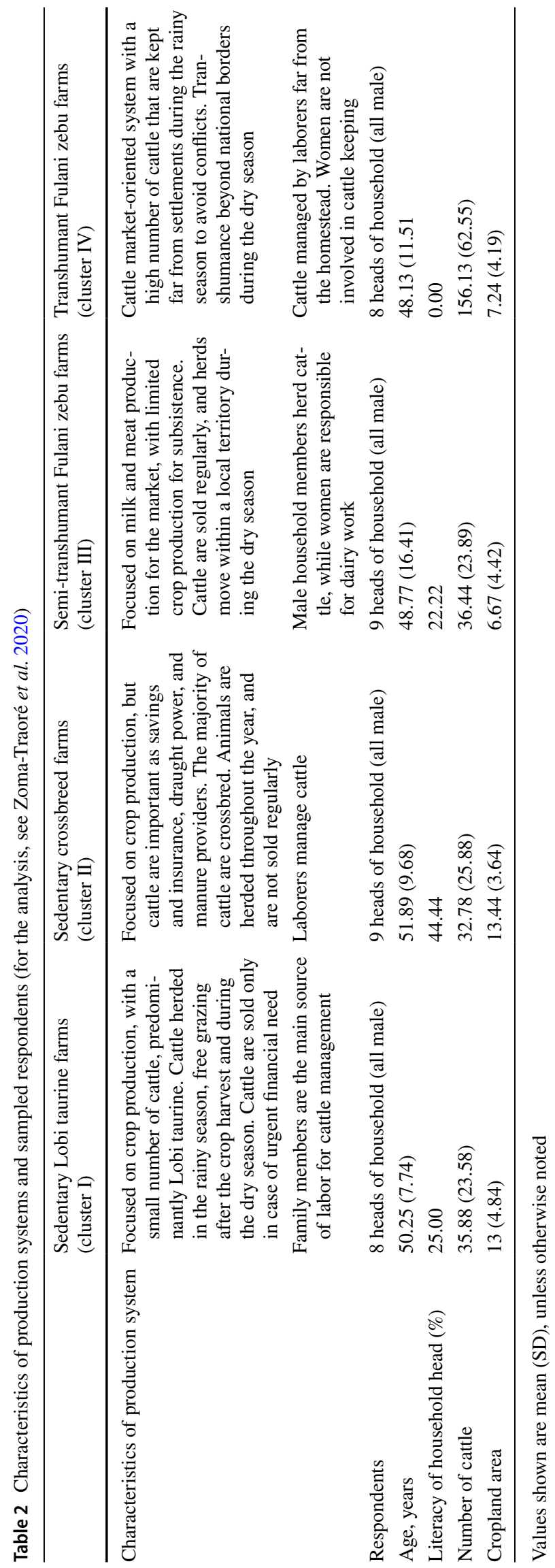




\section{Research Instrument}

The interviews were moderately structured by a guide based on the analytical framework (Appendix 1). While standardized value assessment scales have been developed (e.g., Schwartz 1992), we concluded from our own experience and the literature that such an instrument would be of limited value in the given situation. First, the epistemology of the scale resonates poorly with the reality of the respondents and their livelihood strategies. Second, to derive practical insights, generic value profiles would need to be re-interpreted in relation to additional data on livelihood realities and descriptions.

We therefore used the strategy of indirection (Wengraf 2001) to design questions that would prompt a conversation indicating respondents' beliefs. According to our theoretical framework, belief statements can be considered indicative of individual values. Given ethical concerns related to indirection in empirical social research, the interviewer carefully explained to respondents that we would look at their descriptions and argumentation to understand how and why they made decisions related to cattle breeding or, more generally, their livelihood. For example, the question: "When you tell your friends/family members about a successful year as a farmer/cattle keeper, what do you mention?" was used to initiate a discussion about the respondent's livelihood and related challenges, which at the same time yielded belief statements on the definition of success. These statements, in turn, contained rich evidence on what the respondent valued.

\section{Data Collection and Analysis}

The first author contacted the heads of the sampled households and asked whether they would be willing to share their insights into the realities of agriculture and cattle breeding in more detail. All 34 individuals contacted agreed to participate in the study. Before starting the interviews, we obtained free prior and informed consent from each respondent, including the permission to audiotape the interviews. The respondents chose time, place, and language (Dioula, Mooré, French) for the interview.

The first author transcribed the interviews, and if necessary, translated them to French. We analyzed the transcripts using a combination of (a) deductive coding, according to the domains and sub-domains of the analytical framework (Table 1, e.g., values, livelihood descriptions); and (b) inductive coding. Our goal was to identify emerging themes based on recurring belief statements. We coded the data in atlas.ti Cloud, which allowed us to work in parallel and discuss divergent interpretations, thereby increasing inter-coder reliability. For the detailed analysis (occurrence frequency, code co-occurrence), we exported the hermeneutic unit to atlas.ti 8 for Windows. In the results, cited quotations are labelled with respondent and quotation number (QX:XX), respondent cluster, place and date of the interview.

Differences in the values among the four clusters were assessed for significance using the chi-squared test, followed by pairwise comparisons with Bonferroni adjustments for multiple testing. Statistical differences were considered significant at $\mathrm{p}<0.05$. Spearman's rank correlation analysis was applied to analyze the associations of the different values separately for crop-oriented clusters (I and II) and livestock-oriented clusters (III and IV).

\section{Results}

We report the results following the dimensions of the conceptual framework, which assumes that respondents' values and beliefs are both shaping and being shaped by their livelihood. We begin with the livelihood descriptions, followed by the analysis of values expressed through belief statements.

\section{Livelihood Description}

\section{Landscape Level}

The increasing scarcity of land and resources emerged as the critical livelihood dynamic observed by respondents. The influx of migrants from neighboring regions and changing rainfall patterns have led to growing competition over land and water for cattle and crop production, as explained by respondent 15:

"There is no pasture now, there is no space. Space is limited, people have become numerous, the pastures have become small." (Q15:85, Cluster IV, Loropéni, 20.08.2019)

The respondents considered the main risk factor affecting their livelihood to be the dependence of agriculture and cattle production on weather. Accordingly, respondents across all clusters mentioned sufficient, timely rainfall as the main attribute of a successful year:

"For example, if it doesn't rain well during the month of August and the following months, we say that it has not rained well and that the year will not be good. So, the year depends mostly on rain." (Q20:37, Cluster IV, Kampti, 23.07.2019)

In livestock production, the occurrence of diseases was an additional challenge over which producers felt they had little control. Many respondents strongly expressed their belief in the power of God in setting the course of their livelihood, such as respondent 26 : 
"Ah, it is God who has decided it! Because God created you, what he wants you to do, this is what you will do.” (Q26:97, Cluster II, Loropéni, 02.10.2019)

\section{Regime Level}

In the case of cattle production, the institutional framework was weak, as theft of animals frequently occurred (see Q7:24 below) and veterinary services were difficult to access and afford.

"But right now, there are many thieves; if you leave the cattle like this, you will not even have a single animal after, they will steal." (Q7:24, Cluster I, BouroumBouroum, 25.07.2019)

Animal breeding was not institutionalized at the time of the study. While cattle production was market-oriented, the volatility of prices made it difficult for producers to strategically market cattle products.

\section{Livelihood and Cattle Breeding Strategies}

Across all clusters (Table 2), respondents considered diversification the most promising strategy to achieve good livelihood outcomes. Respondents whose principal activity was crop farming diversified their crop portfolio, typically by investing in cashew growing. Livestock keepers expanded subsistence-oriented crop production. Respondents from all groups were seeking to engage in non-farm activities such as trading and building. However, respondents widely considered agriculture (including crop and livestock production) as being the backbone of their livelihood:

"Whether you are a minister or the president, you have to have a field." (Q33:13, Cluster IV, Loropeni, 02.09.2019)

Respondents from sedentary clusters (I and II) considered the education of the next generation as their main investment strategy, while respondents from transhumant clusters (III and IV) focused on trading and construction activities.

Considering our motivation to gain practical insights for facilitators of CBBPs, we put a particular focus on the respondents' breeding strategies in the interviews. Across all clusters, the standard strategy was to select and keep one dominant mating bull with the herd, as well as two to three smaller bulls as a backup. Owning a bull was generally seen as a sign of achievement. Due to the proximity of enclosures and free-roaming cattle during the dry season, respondents agreed that random breeding was unavoidable and common. The respondents also stressed the advantage that, under this system, they did not have to monitor when cows came into heat, as illustrated by respondent 20 :
"A cow can get up one night and be in heat - so what happens if you have given your bull away? This is why the male is left permanently in the herd so that he can mount the females at any time." (Q20:30, Cluster IV, Kampti, 23.07.2019)

Based on our interviews, we did not find any evidence for organized breeding at the study sites, e.g., through bull sharing. When reflecting on opportunities for communitybased breeding, respondents expressed concern about the risks and costs of sharing animals, such as if others did not treat animals well, if the respondents were accused of not treating animals well, if animals were lost or stolen, or if a bull had to be transported beyond the immediate neighborhood at a high cost.

Finally, some respondents, such as respondent 20, questioned the possibility of improving cattle traits through continuous breeding, suggesting that real improvement would require bringing in animals from abroad:

"Unless it's a bull of a breed from somewhere else, the bulls that are here are the same, (...) we don't want to put them in our herds anymore. (...). You know that if the bulls are not of different breeds, no, no, we don't say that this bull is better than the other, no, no, no." (Q20:40, Cluster IV, Kampti, 23.07.2019)

\section{Respondent Values and Beliefs}

Following the theoretical considerations of this study, we presume that values operate as a formal backdrop for the principles that guide cattle producers in their choices. In pursuit of our goal of understanding the values and beliefs that shape choices by cattle keepers, we report in detail on the five values that occurred most frequently in the hermeneutic unit (Fig. 3). Belief statements indicating the value security occurred most often, followed by achievement and conformity, and at some distance power and self-direction.

\section{Security}

Security emerged from the interviews as the first most important value in the case of cattle-oriented clusters III and IV, or as the second most important value in the case of crop-oriented clusters I and II. Between-group differences were not significant (Table 3). The respondents expressed security-related beliefs mostly in relation to the insecurity of their livelihood due to larger-scale trends and the lack of risk mitigation and management. As illustrated above and described by respondent 31 , livestock keepers reacted at the household level by diversifying livelihood strategies and accumulating savings. 


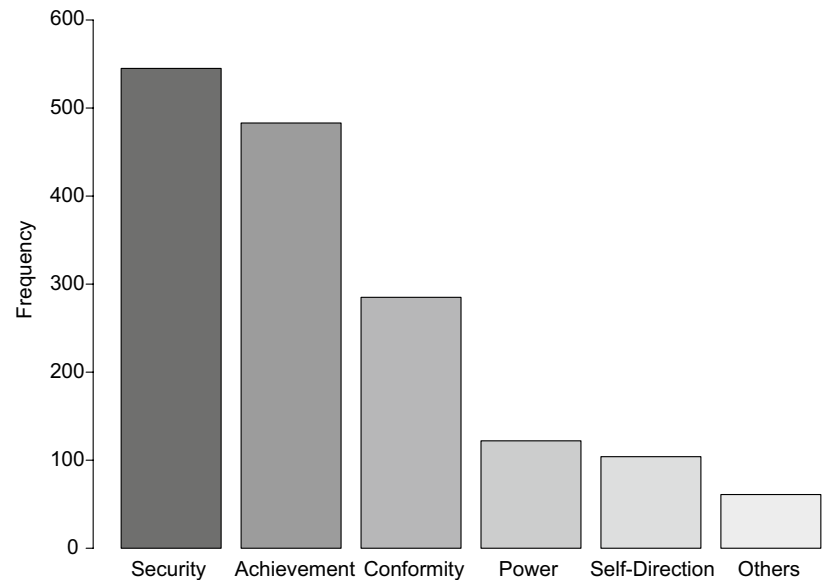

Fig. 3 Frequency of code occurrence: types of values. "Others" includes benevolence, stimulation, universalism, and hedonism

"There is a proverb that says: 'a single axe cannot cut down the tree'. It takes several sharp axes to cut down a tree. Today, if you focus on cattle only, there will be times when diseases can come and ravage your herd then what are you going to sell? So, I tell myself that the two activities have to go hand in hand. I do crop farming and then a little bit of cattle keeping". (Q31:1, Cluster I, Loropéni, 29.08.2019)

In the absence of institutionalized insurance, respondents stored wealth by stockpiling grains and pulses, or by keeping additional cattle, as explained by respondent 27 below. These strategies were seen as most reliable to quickly mobilize cash in times of urgent need.

"Maybe you, working with white people, people know you have money in the bank so people can give you credit. But here in the bush, if a Fulani tells you he has money in the bank, you know that he is lying to you." (Q27:22, Cluster IV, Loropéni, 31.08.2019)

Table 3 Value profiles of respondents by cluster (percentages of total code occurrence)

\begin{tabular}{lllll}
\hline & $\begin{array}{l}\text { Sedentary } \\
\text { Lobi taurine } \\
\text { (Cluster I) }\end{array}$ & $\begin{array}{l}\text { Sedentary } \\
\text { crossbreed } \\
\text { (Cluster II) }\end{array}$ & $\begin{array}{l}\text { Semi-Transhumant- } \\
\text { Zebu } \\
\text { (Cluster III) }\end{array}$ & $\begin{array}{l}\text { Transhumant- } \\
\text { Zebu } \\
\text { (Cluster IV) }\end{array}$ \\
\hline Security & $32 \mathrm{a}$ & $32 \mathrm{a}$ & $36 \mathrm{a}$ & $36 \mathrm{a}$ \\
Achievement & $37 \mathrm{a}$ & $33 \mathrm{ab}$ & $25 \mathrm{bc}$ & $24 \mathrm{c}$ \\
Conformity & $13 \mathrm{a}$ & $15 \mathrm{ab}$ & $22 \mathrm{bc}$ & $23 \mathrm{c}$ \\
Power & $8 \mathrm{a}$ & $9 \mathrm{a}$ & $7 \mathrm{a}$ & $6 \mathrm{a}$ \\
Self-Direction & $6 \mathrm{a}$ & $7 \mathrm{a}$ & $6 \mathrm{a}$ & $6 \mathrm{a}$ \\
Others & $4 \mathrm{a}$ & $3 \mathrm{a}$ & $4 \mathrm{a}$ & $5 \mathrm{a}$ \\
\hline
\end{tabular}

${ }^{a b c}$ Numbers within rows that do not have a common superscript indicate a significant difference at $\mathrm{p}<0.05$ level

\section{Achievement}

Achievement, defined as a large recurring harvest of diverse crops, was the most important value for crop-oriented respondents (clusters I and II). For semi-transhumant and transhumant respondents (clusters III and IV), the number and appearance of animals owned was considered the main characteristic of achievement and ranked second among all values for this group:

"A successful cattle keeper is one who has a lot of animals, he is the one we call a great producer, anyway. A successful farmer is one who cultivates to have many granaries and bags - they are what we call great farmers.” (Q18:20, Cluster III, Kampti, 20.08.2019)

There was a significant association between the type of cluster and the frequency of belief statements related to achievement (Table 3). The cattle-keepers felt competent to select the best animals for breeding and managing their herds optimally given the landscape trends mentioned above, as exemplified by respondent 22 :

"The breeding bull (...) is a bull in good shape, with a good body, his scrotum is well descended, when you see him even you agree. At a glance, you can know that this bull can be big and fit, through his growth." (Q22:18, Cluster III, Kampti, 23.08.2019)

\section{Conformity}

Across all clusters, the respondents highly valued conformity and tradition (e.g., respondent 26 below). Belief statements in this category typically stated how "we" do things "here," and indicated social norms, particularly regarding acceptable behavior (working hard) to achieve wealth or power. There was a significant association between the type of cluster and the frequency of belief statements related to conformity (Table 3).

"My son cannot refuse to cultivate or keep cattle. I myself grew up and saw my parents doing it (laughter). He too has grown up and he has seen me doing it - if he refuses now, he is an idiot, it is his problem, he himself will suffer." (Q26:25, Cluster II, Loropéni, 02.09.2019)

The respondents also considered roles in their communities to be defined based on ethnicity or gender, e.g., Fulani being cattle keepers and herders, and women being responsible for milking and marketing dairy products:

"God created us with cattle. Even if a Fulani is poor, he will buy at least one cattle and tether it in front of 
Table 4 Clusters I and II: correlation between value-code occurrences

\begin{tabular}{lllclc}
\hline & Achievement & Conformity & Power & Security & Self-Direction \\
\hline Achievement & 1.000 & - & - & - & - \\
Conformity & $0.570^{*}$ & 1.000 & - & - & - \\
Power & $0.643^{* *}$ & 0.436 & 1.000 & - & - \\
Security & $0.847^{* *}$ & $0.583^{*}$ & $0.515^{*}$ & 1.000 & - \\
Self-Direction & 0.005 & -0.089 & -0.249 & 0.099 & 1.000 \\
\hline
\end{tabular}

*, ** Correlation significant at the 0.05 and 0.01 levels, respectively his door to look at it every day.” (Q28:40, Cluster IV, Loropéni, 01.09.2019)

\section{Power}

Power (including social recognition, authority, and wealth) emerged as the fourth most frequently stated value. For respondents, achievement translated into power when success became visible for others, thus contributing to social reputation, as explained by respondent 3 :

"You also know that, nowadays, if you have nothing you cannot be in front of people. (...) Someone may come to the village from somewhere else, hear your name and then come, and sleep hungry. He wakes up hungry. If they put you in front of things, what can you do? You can't do anything, you can't develop the village." (Q3:31, Cluster I, Bouroum-Bouroum, 28.07.2019)

Power and conformity were aligned when respondents stated that they did not necessarily wish others to succeed or share their successes with others, including animals:

"We don't want anyone to outdo someone else. (...). He doesn't want his good bull to go and mate with someone else's cattle so that he too has good cattle. This is a great difficulty even." (Q9:39, Cluster II, Bouroum-Bouroum, 27.07.2019)

\section{Self-direction}

Self-direction can be considered diametrically opposed to the more prevalent value of conformity. When respondents expressed beliefs indicating self-direction, they often referred to their children and education, such as respondent 21:

"Well! Like the children, some of them are students, agriculture is not part of their activities. (...) If you force them nowadays, you cannot force the children. The spirit with which they grew up, you leave them with that spirit and do your work." (Q21:4, Cluster II, Kampti, 21.08.2019)

Many respondents considered employment in the public sector or commerce as being a better livelihood than agriculture. They saw education as a main pathway out of the hard livelihood of agriculture:

"Agriculture is a good occupation, but as people say, it will hurt your back. If you do well in school, you will get your job. You are a doctor, you are a Gendarme, you are a policeman, you earn your money by sitting only, to feed yourself, to do whatever you want. I like this." (Q14:6, Cluster I, Bouroum-Bouroum, 13.08.2019)

\section{Correlation of Values}

To further investigate the respondents' value profiles and their possible relation to different livelihood strategies, we explored the correlation of code-occurrences separately for cropping-oriented clusters (I and II) and livestock-oriented clusters (III and IV). The results (Tables 4 and 5) corroborate the interpretation that respondents from clusters I and II considered achievement and power as main pathways towards security. In clusters III and IV, however, conformity positively correlated with security, but the more individualistic values power and self-direction negatively correlated with
Table 5 Clusters III and IV: correlation between value-code occurrences

\begin{tabular}{lccccc}
\hline & Achievement & Conformity & Power & Security & Self-Direction \\
\hline Achievement & 1.000 & - & - & - & - \\
Conformity & 0.454 & 1.000 & - & - & - \\
Power & -0.228 & 0.054 & 1.000 & - & - \\
Security & $0.624^{* *}$ & $0.652^{* *}$ & -0.199 & 1.000 & - \\
Self-Direction & -0.297 & -0.100 & 0.458 & -0.362 & 1.000 \\
\hline
\end{tabular}


security. Livestock-oriented respondents, but not crop-oriented ones, positively associated power with self-direction (significant at $\mathrm{p}<0.05$ ).

\section{Discussion}

The purpose of this study was to understand the values and beliefs that shape choices by cattle keepers in southwestern Burkina Faso. Based on our findings, we draw three main conclusions which should be considered if a change in breeding practices is to be fostered.

\section{Integration of Security Concerns and Visible Achievements}

Across all clusters, the vulnerability of their livelihood was the respondents' greatest concern, which is consistent with the strong value that they assigned to security. Earlier research in the region confirms the perceptions of the challenges to livestock production at the landscape level (e.g., climate dynamics) and regime level (e.g., institutional framework) (Koutou et al. 2016; Zoma-Traoré et al. 2020). Several studies in the region have also highlighted the constant struggle to manage livelihood vulnerability (e.g., Ilatsia et al. 2012; Traoré et al. 2017). Despite this, smallholders can be rather skeptical of changing their practices, particularly when benefits are not obvious or immediate (e.g., Wiggins 2016). Therefore, we suggest that for a CBBP to be successful in the region, it should put the reduction of current livelihood risks at the center of its narrative and strategy. Participating in the CBBP and exploring new cattle breeding strategies should include opportunities to reduce or buffer losses, even beyond livestock keeping.

Secondly, we propose that the CBBP process accounts for the motivation to be judged as successful by others (achievement). Considering the central role of achievement and power, particularly for crop-oriented respondents, the potential outcomes of changing cattle breeding practices should be made visible and framed as a pathway towards success and social recognition. In other regions, breeding stock from CBBPs has led to significantly higher prices (Haile et al. 2020). Consistent with our results, previous work has highlighted the importance of being seen as a "good farmer," as well as the difficulty of seeing immediate benefits from livestock breeding (e.g., Burton 2012; Haile et al. 2019, 2020).

We further suggest that long-term commitment and trust among stakeholders will be key to establishing a partnership that will last long enough to see the benefits of breeding efforts. Previous studies have highlighted the pivotal role of a lead stakeholder in such a partnership, who is seen and accepted as being unbiased (Probst et al. 2019; Ndah et al.
2020). Indeed, several studies show that breeding programs can fail if the trust in leadership and organization is low (Camara et al. 2019; Wurzinger and Gutierrez 2017). In sum, a shared, transparent understanding of the potential and likely benefits of systematic breeding and how it can be organized should lie at the heart of a CBBP.

\section{Integration of Existing Norms}

Our results illustrate the commonly practiced strategies in cattle breeding in the region. These strategies show the characteristics typical of a social norm: the respondents related their strategies to their peer group and the area, framed their choices as unavoidable and had clear concepts of (un)acceptable behaviors. Staying within these boundaries was important for respondents, particularly those in livestock-oriented households, who clearly associated conformity with security. The respondents also underlined their confidence in mastering livestock-breeding using conventional practices. We suggest that establishing a CBBP requires carefully integrating established norms into a new narrative of livestock breeding. Earlier research has shown that a change in practices is not only challenging at the individual level but can be seen as a role deviation that is sanctioned by the community (Hauser et al. 2016). As a first step, breeding programs would thus have to understand existing norms and practices, as argued by earlier studies (e.g., Kosgey et al. 2006). Respondents will be reluctant to change breeding strategies that are seen as the 'default,' a bias that has been shown to be related to loss-aversion and the cognitive effort required to learn and evaluate new options (e.g., Kahneman et al. 1991). Several studies have described cases of breeding programs that did not align sufficiently with participants' norms (e.g., Ilatsia et al. 2012; Leroy et al. 2015). We conclude that a CBBP may increase its appeal by building on existing collaborative practices (farm labor, hunting) and by sensitively developing a locally adapted version of systematic, community-based breeding as the new default.

\section{Addressing Organizational and Technical Challenges}

While the focus of this study is on values and beliefs that shape cattle breeding, our results also highlight organizational and technical issues. Group mating was the standard breeding strategy among our respondents, as also shown in similar cases (e.g., Ilatsia et al. 2012; Ejlertsen et al. 2013). Systematic breeding efforts need to be adequately integrated with current practices of free-roaming and group mating, which may require adapted cattle management arrangements. The question of how such arrangements can be put 
into place is a key aspect of a CBBP. Possibilities to institutionalize breeding have been discussed for many years (e.g., Haile et al. 2014). To ensure the necessary buy-in of cattle-keepers, the institutional structure should emerge from interactions within the community. A promotor of CBBP could suggest various ideas to the community as a starting point for discussion, for example: (1) bull-sharing groups that agree on castrating all bulls except the selected breeding bulls, which could be rotated to other groups consecutively as agreed on by the community; (2) common herding of cows in the community, joined only by selected mating bulls; (3) a formal breeders' association that works towards the common interests of all members; or (4) castration of inferior bulls by all cattle keepers.

\section{Conclusion}

Given the importance of cattle production to livelihoods in southwestern Burkina Faso, and the need for novel approaches to cattle management and breeding, the main purpose of our study was to understand cattle keepers' values and beliefs. The respondents observed that their livelihoods were under increasing threat from resource scarcity, changing climate, and cattle diseases. Current institutional arrangements and market opportunities mitigate these threats only partly. In response, the respondents diversify their livelihood strategies but maintain established cattle and crop production approaches. Nevertheless, the vulnerability of their livelihood remains the respondents' greatest concern, and their dominant value is security closely linked to achievement in terms of harvest and animal quantity. Livestock-oriented respondents particularly valued conformity with accepted social roles, while crop-oriented respondents particularly valued achievement and power. We conclude that to preserve local cattle breeds and innovate management and breeding practices, a CBBP will have to make the reduction of livelihood risks central and carefully integrate established norms in a new narrative of livestock keeping. A locally adapted institutionalization of systematic, community-based breeding could build on existing collaborative practices but would require novel arrangements for cattle keeping and feeding. While localized scientific expertise may support the development of such arrangements, we consider trusted leadership emerging from the community as pivotal for a longer-term innovation process.

Supplementary Information The online version contains supplementary material available at https://doi.org/10.1007/s10745-021-00240-1.

Acknowledgements We are grateful to all farmers and livestock technicians for their active participation in the research activities. We also acknowledge help from Karambiri Medina in preparing the map.
Author Contributions Conceptualization: B.Z.-T., L.P., M.W., J.S., S.O.-K., A.S., A.T.; Methodology: L.P., B.Z.-T.; Investigation: B.Z.T.; Analysis: B.Z.-T., L.P., N.K., J.S., Writing - Original Draft: B.Z.-T., L.P., M.W.; Writing -Review \& Editing: S.O.-K., A.S., D.O., B.Y., A.T., N.K., G.M., P.A.B., O.A.M., J.S., B.Z.-T., M.W., L.P.; Funding Acquisition: J.S., P.A.B, A.S.; Supervision: M.W., L.P., J.S.

Funding Open access funding provided by University of Natural Resources and Life Sciences Vienna (BOKU). The research was funded by the Austrian Development Agency and the Austrian Partnership Programme in Higher Education and Research for Development (APPEAR 120).

\section{Declarations}

Ethical Approval Anonymized data that support the findings of this study are available on request from the corresponding author L.P. The data are not publicly available because they contain information that could compromise respondent privacy.

All research undertaken for this study adhered to relevant Burkinabé, EU, and Austrian legislation including the EU General Data Protection Regulation (GDPR), as well as the ethical regulations of BOKUUniversity of Natural Resources and Life Sciences, Vienna. To secure the confidentiality, accuracy, and security of the data, the following measures were taken: (1) only necessary data were collected (data minimization principle); (2) a pseudonymization strategy was applied; (3) data were available to the research team only after blinding (anonymization) by the team member collecting the data; (4) raw data are stored on secure servers; and (5) identifiable personal data will never be published.

Conflict of Interests The authors declare that there is no conflict of interest.

Open Access This article is licensed under a Creative Commons Attribution 4.0 International License, which permits use, sharing, adaptation, distribution and reproduction in any medium or format, as long as you give appropriate credit to the original author(s) and the source, provide a link to the Creative Commons licence, and indicate if changes were made. The images or other third party material in this article are included in the article's Creative Commons licence, unless indicated otherwise in a credit line to the material. If material is not included in the article's Creative Commons licence and your intended use is not permitted by statutory regulation or exceeds the permitted use, you will need to obtain permission directly from the copyright holder. To view a copy of this licence, visit http://creativecommons.org/licenses/by/4.0/.

\section{References}

Ajzen, I. (1991). The theory of planned behavior. Organizational Behavior And Human Decision Processes 50: 179-211. https:// doi.org/10.1016/0749-5978(91)90020-T

Alvaredo, F., L. Chancel, T. Piketty, E. Saez and G. Zucman. (2018). World Inequality Report (2018) Cambridge: Belknap Press.

Bassi, E. M., E. Goddard and J. R. Parkins (2019). "That's the Way We've Always Done It": A Social Practice Analysis of Farm Animal Welfare in Alberta. Journal of Agricultural and Environmental Ethics 32: 335-354. https://doi.org/10.1007/s10806-019-09777-0

Belemsaga, D. M. A., Y. Lombo, S. Thevenon and S. Sylla (2005). Inventory analysis of West African cattle breeds. In Applications of Gene-Based Technologies for Improving Animal Production 
and Health in Developing Countries, 167-173. Dordrecht: Springer.

Burton, R. J. F. (2012). Understanding Farmers' Aesthetic Preference for Tidy Agricultural Landscapes: A Bourdieusian Perspective. Landscape Research 37: 51-71. https://doi.org/10.1080/01426397. 2011.559311

Camara, Y., N. Moula, F. Sow, M. M. Sissokho and N. AntoineMoussiaux. (2019). Analysing innovations among cattle smallholders to evaluate the adequacy of breeding programs. Animal 13: 417-426. https://doi.org/10.1017/S1751731118001544

Chambers, R., A. Pacey and L. A. Thrupp (1989). Farmer first: farmer innovation and agricultural research. London: Technology Publications.

Cherlet, M., C. Hutchinson, J. Reynolds, J. Hill, S. Sommer and G. Von Maltitz. (2018). World Atlas Of Desertification: Rethinking Land Degradation And Sustainable Land Management. Publications Office of the European Union.

Darnhofer, I. (2020). Farming from a Process-Relational Perspective: Making Openings for Change Visible. Sociologia Ruralis 60: 505528. https://doi.org/10.1111/soru.12294

Dessie, T., Mwai, O. (2019). The Story of Cattle in Africa: Why Diversity Matters. Nairobi: ILRI, Rural Development Administration, Republic of Korea and AU-IBAR, Bureau for Animal Resources.

Ejlertsen, M., J. P. and K. Marshall (2013). Traditional breeding objectives and practices of goat, sheep and cattle smallholders in The Gambia and implications in relation to the design of breeding interventions. Tropical Animal Health And Production 45: 219229. https://doi.org/10.1007/s11250-012-0194-1

El Bilali, H., M. Hauser, S. Berjan, O. Miseckaite, \& L. Probst. (2017). Rural livelihoods transitions: towards an integration of the sustainable livelihoods approach and the multi-level perspective. In Proceedings of the International Scientific conference on Rural Development, Aleksandras Stulginskis University Lithuania, November 23-2 2017.

Etana D Wesenbeeck VanCFA T Cock Buning De (2020). Sociocultural aspects of farmers' perception of the risk of climate change and variability in Central Ethiopia Climate and Development 1-13 https://doi.org/10.1080/17565529.2020.1737796

FAO (2013). In Vivo Conservation of Animal Genetic Resources. Animal Production and Health Guidelines. Rome: Food and Agriculture Organization of the United Nations.

FAO (2015). Second state of the world's animal genetic resources for food and agriculture. Rome: Food and Agriculture Organization of the United Nations.

Grace, D., Ekta P. and T. F. Randolph (2020). Tsetse and Trypanosomiasis Control in West Africa, Uganda and Ethiopia: ILRI's Role in the Field. McIntire, J. and Grace, D. (eds), The impact of the International Livestock Research Institute. Nairobi, Kenya: ILRI and Wallingford, UK: CABI: 148-163.

Haile, A., T. Dessie and B. A. Rischkowsky (2014). Performance of indigenous sheep breeds managed under community-based breeding programs in the highlands of Ethiopia: Preliminary results. Addis Ababa: ICARDA.

Haile, A., T. Getachew, T. Mirkena, G. Duguma, S. Gizaw, M. Wurzinger, J. Soelkner, O. Mwai, T. Dessie, A. Abebe, Z. Abate, T. Jembere, M. Rekik, R. N. B. Lobo, J. M. Mwacharo, Z. G. Terfa, G. T. Kassie, J. P. Mueller and B. Rischkowsky (2020). Community-based sheep breeding programs generated substantial genetic gains and socioeconomic benefits. Animal: 14(7):1362-1370. https://doi.org/10.1017/ S1751731120000269

Haile, A., S. Gizaw, T. Getachew, J. P. Mueller, P. Amer, M. Rekik and B. Rischkowsky (2019) Community-based breeding programmes are a viable solution for Ethiopian small ruminant genetic improvement but require public and private investments. Journal of Animal Breeding and Genetics 136: 319-328. https:// doi.org/10.1111/jbg.12401
Hansson, H. and K. Suvi (2018). Farmers' mental models of change and implications for farm renewal - A case of restoration of a wetland in Sweden. Journal of Rural Studies 60: 141-151. https:// doi.org/10.1016/j.jrurstud.2018.04.006

Hauser, M., M. Lindtner, S. Prehsler, L. Probst (2016). Farmer participatory research: Why extension workers should understand and facilitate farmers' role transitions. Journal of Rural Studies, 47, 52-61. https://doi.org/10.1016/j.jrurstud.2016.07.007.

Ilatsia, E. D., R. Roessler, A. K. Kahi, H.-P. Piepho and V. Zárate (2012). Production objectives and breeding goals of Sahiwal cattle keepers in Kenya and implications for a breeding programme. Tropical Animal Health and Production 44: 519-530. https://doi. org/10.1007/s11250-011-9928-8

INSD (2018). Annuaire statistique. Institut National de la Statistique et de la Demographie, Ministere de 1'Economie et des Finances. Ouagadougou: Burkina Faso.

IPCC (2019). Climate Change and Land. Geneva: Intergovernmental Panel on Climate Change.

Jahel, C., X. Augusseau and D. Lo Seen (2018). Modelling cropping plan strategies: What decision margin for farmers in Burkina Faso? Agricultural Systems 167: 17-33. doi: https://doi. org/https://doi.org/10.1016/j.agsy.2018.08.004

Jarrett, F. G. (1985). Sources and models of agricultural innovation in developed and developing countries. Agricultural Administration 18: 217-234. https://doi.org/10.1016/0309-586X(85)90092-5

Kahneman, D., J. L. Knetsch and R. H. Thaler (1991). Anomalies: The Endowment Effect, Loss Aversion, and Status Quo Bias. Journal of Economic Perspectives 5: 193-206. https://doi.org/10.1257/ jep.5.1.193

Kassie, M., B. Shiferaw and G. Muricho (2011). Agricultural Technology, Crop Income, and Poverty Alleviation in Uganda. World Development 39: 1784-1795. https://doi.org/10.1016/j.worlddev. 2011.04.023

Klerkx, L., B. van Mierlo and C. Leeuwis (2012). Evolution of systems approaches to agricultural innovation: concepts, analysis and interventions. In Farming Systems Research into the 21st Century: The New Dynamic, eds. .: Springer, Dordrecht, Netherlands, pp. 457-483

Kosgey, I. S., R. L. Baker, H. M. J. Udo and J. A. M. Van Arendonk (2006). Successes and failures of small ruminant breeding programmes in the tropics: a review. Small Ruminant Research 61: 13-28. https://doi.org/10.1016/j.smallrumres.2005.01.003

Koutou, M., M. Sangaré, M. Havard, E. Vall, L. Sanogo, T. Thombiano and D. S. Vodouhe (2016). Adaptation des pratiques d'élevage des producteurs de l'Ouest du Burkina Faso face aux contraintes foncières et sanitaires. Agronomie Africaine 28: 13-24.

Leroy, G., R. Baumung, P. Boettcher, B. Scherf and I. Hoffmann (2015). Review: Sustainability of crossbreeding in developing countries; definitely not like crossing a meadow.... Animal 10: 262-273. doi: https://doi.org/10.1017/S175173111500213X

Martin-Collado, D., T. J. Byrne, C. Diaz and P. R. Amer (2018). Complexity of animal breeding choice making. Journal of Animal Breeding and Genetics 135: 395-409. doi: https://doi.org/10. $1111 /$ jbg. 12360

McIntyre, B. D., H. R. Herren, J. Wakhungu and R. T. Watson. (2009). Agriculture at a Crossroads: Global Report (pp. 590). Washington DC: International Assessment of Agricultural Knowledge Science and Technology for Development (IAASTD).

Meijer, Seline S., D. Catacutan, C. Oluyede, A. Gudeta, W. Sileshi and M. Nieuwenhuis (2015). The role of knowledge, attitudes and perceptions in the uptake of agricultural and agroforestry innovations among smallholder farmers in sub-Saharan Africa. International Journal of Agricultural Sustainability 13: 40-54. doi: https://doi. org/10.1080/14735903.2014.912493 
Mongin, P. (1997). Expected utility theory. In: Davis J, Hands W, Maki U, editors. Handbook of economic methodology. London, UK: Edward Elgar; pp.342-350.

Mopaté L.Y. (2015). Caractéristiques, menaces et nécessité de conservation in situ du taurin Baoulé dans les savanes du Sud-Ouest du Burkina Faso. Journal of Applied Biosciences 93:8713 - 8726

Mopaté, L. Y., M. J. B. Kamuanga, S. Hamadou and C. Y. KaboréZoungrana (2014). Evaluation des pratiques paysannes de conservation in situ du taurin Baoulé au Sud-Ouest du Burkina Faso. Animal Genetic Resources 54: 171-178. doi: https://doi.org/10. 1017/S2078633614000022

Mueller, J. P., B. Rischkowsky, A. Haile, J. Philipsson, O. Mwai, B. Besbes, A. Valle Zárate, M. Tibbo, T. Mirkena, G. Duguma, J. Sölkner and M. Wurzinger (2015). Community-based livestock breeding programmes: essentials and examples. Journal of Animal Breeding and Genetics 132: 155-168. doi: https://doi.org/10. $1111 /$ jbg. 12136

Ndah, H., L. Probst, S. Kaweesa, P. Kuria, S. Mkomwa, P. Rodrigues, G. Basch, G. Uckert, S. Sieber, A. Knierim, P. Zander and J. Schuler (2020). Improving farmers' livelihoods through conservation agriculture: options for change promotion in Laikipia, Kenya. International Journal of Agricultural Sustainability 18: 212-231. doi: https://doi.org/10.1080/14735903.2020.1746063

Norman, D. W. (2002). The farming systems approach: A historical perspective. Presentation held at the 17th Symposium of the International Farming Systems Association in Lake Buena Vista, Florida, USA, 17-20 November 2002.

Ouédraogo, D., A. Soudré, S. Ouédraogo-Koné, B. Zoma, B. Yougbaré, N. Khayatzadeh, P. Burger, G. Mészáros, A. Traoré, O. Mwai, M. Wurzinger and J. Sölkner (2020). Breeding objectives and practices in three local cattle breed production systems in Burkina Faso with implication for the design of breeding programs. Livestock Science 232: 103910. doi: https://doi.org/10.1016/j.livsci. 2019.103910

Pradhananga, A. K. and M. A. Davenport (2019). Predicting Farmer Adoption of Water Conservation Practices Using a Norm-based Moral Obligation Model. Environmental Management 64: 483496. doi: https://doi.org/10.1007/s00267-019-01186-3

Probst, L., H. T. Ndah, P. Rodrigues, G. Basch, K. Coulibaly and J. Schuler (2019). From adoption potential to Transformative Learning around Conservation Agriculture. The Journal of Agricultural Education and Extension 25: 25-45. doi: https://doi.org/10.1080/ 1389224X.2018.1520733

Reij, C., Tappan, G., \& Smale, M. (2009). Agroenvironmental transformation in the Sahel: Another kind of Green Revolution (Vol. 914). IFPRI

Röling, N. (2009). Pathways for impact: scientists' different perspectives on agricultural innovation. International Journal of Agricultural Sustainability 7: 83-94. doi: https://doi.org/10.3763/ijas. 2009.0043

Schut, M., L. Klerkx, M. Sartas, D. Lamers, M. Mc Campbell, I. Ogbonna, P. Kaushik, K. Atta-Krah and C. Leeuwis (2016) Innovation platforms: experiences with their institutional embedding in agricultural research for development. Experimental Agriculture 52: 537-561. doi: https://doi.org/10.1017/S001447971500023X

Schwartz, S. H. (1992). Universals in the Content and Structure of Values: Theoretical Advances and Empirical Tests in 20 Countries. In Advances in Experimental Social Psychology, ed. Mark P. Zanna, 1-65. New York: Academic Press. 6
Schwartz, S. H. (1994) Are There Universal Aspects in the Structure and Contents of Human Values? Journal of Social Issues 50: 19-45. doi: https://doi.org/10.1111/j.1540-4560.1994.tb01196.x

Sokouri D.P., Yapi-Gnaore C.V., N'Guetta A.S.P., Loukou N.E., Kouao B.J., Toure G., Sangare A. et Kouassi A., (2009). Utilisation et gestion des races taurines locales sous la pression des croisements avec les zébus dans les régions Centre et Nord de la Côte d'Ivoire. Journal of Animal \& Plant Sciences. 5/2, $456-465$.

Soudré, A., Ouédraogo-Koné, S., Wurzinger, M., Müller, S., Hanotte, O., Ouédraogo, A.G., Sölkner, J. (2013). Trypanosomosis: A priority disease in tsetse-challenged areas of Burkina Faso. Tropical Animal Health 45, 497-503.

Stern, P. C., T. Dietz, T. Abel, G. A. Guagnano and L. Kalof. (1999). A value-belief-norm theory of support for social movements: The case of environmentalism. Human Ecology Review: 81-97.

Traoré, A., Koudandé, D.O., Fernández, I., Soudré, A., Granda, V., Álvarez, I. Diarra, S., Diarra, F., Kaboré, A., Sanou, M., Tamboura, H.J. and F. Goyache (2015). Geographical assessment of body measurements and qualitative traits in West African cattle. Tropical Animal Health and Production 47: 1505-1513. doi: https://doi. org/10.1007/s11250-015-0891-7

Traoré, S. A., A. Markemann, C. Reiber, H. P. Piepho and A. Valle Zárate (2017). Production objectives, trait and breed preferences of farmers keeping N'Dama, Fulani Zebu and crossbred cattle and implications for breeding programs. Animal 11: 687-695. doi: https://doi.org/10.1017/S1751731116002196

Wengraf, T. (2001). Qualitative Research Interviewing: Biographic Narrative and Semi-Structured Methods. Sage.

Wiggins, S., (2016). Risk aversion among smallholder farmers in Uganda. ODI: London.

Wurzinger, M. and G. Gutierrez (2017). Analysis of a multi-stakeholder process during the start-up phase of two community-based llama breeding programs in Peru. Livestock Research for Rural Development 29.

Yougbaré, B., Soudré, A., Ouédraogo, D., Zoma, B.L., Tapsoba, A. S. R., Sanou, M., Ouédraogo-Koné, S., Burger, P., Wurzinger, M., Khayatzadeh, N., Tamboura, H.H., Traoré, A., Sölkner, J., Mészáros, G. (2020). Morphometric characterization of purebred and crossbred Baoulé cattle in Burkina Faso. Acta Agriculturae Scandinavica, Section A - Animal Science, https://doi.org/10. 1080/09064702.2020.1825785

Zoma-Traoré, B., A. Soudré, S. Ouédraogo-Koné, N. Khayatzadeh, L. Probst, J. Sölkner, G. Mészáros, P. A. Burger, A. Traoré, M. Sanou, G. M. S. Ouédraogo, L. Traoré, D. Ouédraogo, B. Yougbaré and M. Wurzinger (2020). From farmers to livestock keepers: a typology of cattle production systems in southwestern Burkina Faso. Tropical Animal Health And Production 52, 2179-2189. https:// doi.org/10.1007/s11250-020-02241

Zoma-Traoré, B., Probst, L., Ouédraogo-Koné, S., Soudré, A., Ouédraogo, D., Yougbaré, B., Traoré, A., Khayatzadeh, N., Mészáros , G., Burger, P.A., Mwai, O.A., Sölkner, J., Wurzinger M. and D. Martin-Collado, (2021). Livestock keepers' attitudes: Keystone of effective community-based breeding programs. Sustainability, 13(5), 1-14. https://doi.org/10.3390/su13052499

Publisher's Note Springer Nature remains neutral with regard to jurisdictional claims in published maps and institutional affiliations. 